\title{
PENGARUH PENAMBAHAN GULA TERHADAP LAMA PENYIMPANAN KELAPA MUDA DALAM SIRUP
}

\author{
EFFECT OF SUGAR ADDITION ON STORAGE TIME OF YOUNG COCONUT IN \\ SYRUP
}

\author{
Hilda F.G. Kaseke, Ardi Makalalag \\ Baristand Industri Manado \\ J. Diponegoro No. 21-23 Manado \\ email: kasekehilda@yahoo.co.id \\ Diterima 06-04-2015, Disetujui tgl 14-04-2015
}

\begin{abstract}
ABSTRAK
Penelitian ini bertujuan untuk melihat pengaruh konsentrasi gula terhadap lama penyimpanan kelapa muda dalam sirup. Metode Penelitian menggunakan metode rancangan acak lengkap dengan dua faktor yaitu,Faktor A: Variasi penambahan gula, dimana A0=tanpa penambahan gula, A1=penambahan gula 55\%, A2=penambahan gula $65 \%$, dan $A 3=$ penambahan gula $75 \%$. Sedangkan Faktor $B$ adalah lama penyimpanan, dimana $\mathrm{B} 0=$ tanpa penyimpanan, $\mathrm{B} 1=$ ama penyimpanan 2 minggu, B2=lama penyimpanan 4 minggu, dan B3=lama penyimpanan 6 minggu. Hasil uji organoleptik menunjukkan bahwa aroma mendapatkan penilaian dengan kisaran angka 3,12-3,62 (masih disukai oleh panelis), rasa mendapatkan penilaian dengan kisaran 3,59-3,75 (agak suka sampai suka), warna mendapat penilaian dengankisaran 4,314,86 (suka hingga sangat suka), serta tekstur mendapat penilaian dengan kisaran 3,79-3,84(suka sampai sangat suka). Berdasarkan pengujian organoleptik tersebut di atas diperoleh hasil yang terbaik atau yang paling disukai adalah produk dengan perlakuan A1 dengan lama penyimpanan sampai 6 minggu. Produk olahan kelapa muda yang dikemas dalam wadah botol jar memiliki potensi untuk di ekspor.

Kata kunci : kelapa muda, kelapa muda dalam sirup gula, penyimpanan
\end{abstract}

\begin{abstract}
This study aims to look at the effect of sugar concentration on the storage time of young coconut in syrup. Research was undertaken through a factorial experiment in a completely randomized design with two factors, namely Factor A: variation of sugar addition, where A0: without sugar addition, A1: sugar addition of $55 \%$, A2: sugar addition of $65 \%$, and A3: sugar addition of $75 \%$. While factor B: storage time, where B0: no storage time, B1: 2 weeks of storage time, B2: 4 weeks of storage time, and B3: 6 weeks of storage time. Organoleptic test showed that the smell of products was valued at 3.59-3.75 (rather like to like); the taste of product was valued at 3.59-3.75 (rather like to like), the color of products was valued at 4,31-4,86 (like to extreme like), and the texture was valued at 3,79-3,84(like to extreme like). Based on organoleptic test it was known that the most preferred young coconut in syrup product was produced through treatment A1 with storage time up to 6 weeks. Young coconut processed products packaged in a bottle jar container have the potency to be exported.
\end{abstract}

Keywords: young coconut, young coconut in sugar syrup, storage time

\section{PENDAHULUAN}

Sulawesi Utara terkenal sebagai daerah Nyiur Melambai, karena potensi kelapa yang cukup besar.Berdasarkan data dari Dinas Perkebunan Tahun 2013 Luas areal tanaman kelapa di Sulawesi Utaraadalah $283.486,57$ ha dengan produksi $282.190,01$ ton.

Dengan adanya potensi tanaman kelapa yang cukup melimpah, maka usaha diverifikasi produk kelapa memiliki peluang untuk dapat dikembangkan.Bagian dari buah kelapa yang dominan dimanfaatkan adalah daging buah dan umumnya daging buah kelapa dibuat kopra, santan, minyak goreng, kue kelapa, virgin coconut oil dsb ${ }^{1}$.

Buah kelapa muda merupakan salah satu produk tanaman tropis yang unik karena disamping komponen daging buahnya dapat langsung dikonsumsi, juga komponen air buahnya dapat langsung diminum tanpa 
melalui pengolahan. Keunikan ini ditunjang oleh sifat fisik dan komposisi kimia daging dan air kelapa, sehingga produk ini sangat digemari konsumen baik anak-anak maupun orang dewasa ${ }^{2}$.

Ditinjau dari wilayah penyebarannya, tanaman kelapa menyebar di seluruh pelosoktanah air walaupun kepemilikan setiap keluarga petani rata-rata hanya sekitar $1,1 \mathrm{ha} / \mathrm{KK}(2)^{3}$. Oleh karena itu bagi masyarakat pedesaan mengkonsumsi buah kelapamuda dapat dilakukan sesaat setelah panen. Akan tetapi bagi masyarakat perkotaan mengkonsumsi buah kelapa muda diperlukan waktu untuk membeli di pasarpasar tradisionalatau di pinggiran jalan raya yang menjual kelapa muda, sehingga seringkali kesegarannya telah berkurang yang menyebabkan citarasa khas kelapa muda tidak diperoleh.Oleh karena itu diperlukan upaya pengolahan untuk mempertahankan mutunya setelah panen, sehingga cita rasa khas buah kelapa muda dapat juga dinikmati oleh konsumen yang jauh dari sentra-sentra produksi kelapa.

Buah kelapa muda selain bernilai ekonomi tinggi, daging buahnya memiliki komposisi gizi yang cukup baik, antara lain mengandung asam lemak dan asam amino esensial yang sangat dibutuhkan tubuh. Sedangkan air kelapa selain sebagai minuman segar juga mengandung bermacam-macam mineral, vitamin dan gula serta asam amino esensial sehingga dapat dikategorikan sebagai minuman ringan bergizi tinggidan dapat menyembuhkan berbagai penyakit ${ }^{4}$. Akan tetapi bagi sebagian konsumen, mengkonsumsi daging buahnya hanya sebagai pelengkap setelah minum airnya.
Di Sulawesi Utara pengolahan daging buah kelapa muda selain sebagai pencampur dalam es buah kelapa muda, juga merupakan bahan baku pencampur dalam pembuatan kue daerah tradisional dan pembuatan kue klapertart yang sekarang menjadi oleh-oleh bagi turis yang datang ke daerah ini, baik turis lokal maupun Internasional.Kue klapertart terksturnya lunak termasuk kue basah yang tidak bisa disimpan lama.Kue klapertaart dibuat kering atau pun keras supaya tahan lama, akan memiliki rasa yang tidak enak.

Dalam pengolahan kue klapertart maupun minuman segar, kelapa yang sudah dibuka harus segera digunakan karena akan cepat mengalami kerusakan apabila tidak segera digunakan.

Penanganan buah kelapa muda setelah panen tidak berbeda dengan buahbuahantanaman hortikultura. Untuk mempertahankan mutunya diperlukan upaya penanganan pascapanen, antara lain cara pengolahan, pengawetan, pengemasan dan penyimpanan ${ }^{5}$. Beberapa hasil penelitian untuk mempertahankan mutu buah kelapa muda dalam bentuk buah utuh, atau sebagian sabutnya telah dikupas, pengolahan daging dan air buah kelapa menjadi berbagai produk, telah dilaporkan ${ }^{4}$

Penelitian buah kelapa muda ini, dilakukan dengan tujuan untuk memberikan informasi tentang teknologi pengolahan daging kelapa muda agar mutunya dapat dipertahankan sehingga diharapkan dapat menunjang usaha komersialisasi atau Industri pengolahan kelapa muda dan bisa menjadi salah satu produk untuk diekspor. 


\section{Tujuan}

Untuk mengetahui pengaruh konsentrasi gula terhadap lama penyimpanan kelapa muda dalam sirup.

\section{Ruang Lingkup}

Penelitian ini meliputi:

1. Pembuatan/pengolahan kelapa muda dalam larutan gula

2. Lama penyimpanan.

\section{BAHAN DAN METODE}

\section{Waktu dan Tempat Penelitian}

Penelitian dilaksanakan selama Sepuluh bulan, mulai bulan Februari-November 2015. Penelitian dilaksanakan di laboratorium BaristandIndustri Manado.

\section{Bahan dan Alat}

Bahan yang digunakan dalam penelitian ini, yaitu daging buah kelapa muda, gula, pengawet (benzoate). Alat yang digunakan adalah botol jar, kantong plastik, panci, loyang, gayung, piring, sendok besar timbangan gelas ukur, talenan dll.

\section{Metode Penelitian}

Penelitian dilaksanakan dalam dua tahap, yaitu penelitian pendahuluan dan penelitian lanjutan.

Penelitian lanjutan menggunakan metode rancangan acak lengkap dan 2 faktor yaitu:

Faktor $\mathrm{A}=$ variasi gula, dimana

$\mathrm{A} 0=$ tanpa penambahan gula $(0 \%)$

$\mathrm{A} 1=$ penambahan gula $55 \%$

$\mathrm{A} 2$ = penambahan gula $65 \%$

A3 = penambahan gula $75 \%$. Dan

Faktor B = Lama Penyimpanan, dimana:
$\mathrm{B} 0$ = Penyimpanan 0 Minggu

B1 = Penyimpanan 2 minggu

B2 = Penyimpanan 4 minggu

B3 = Penyimpanan 6 minggu .

Dengan dua kali pengulangan

\section{Prosedur Penelitian}

1. Buah kelapa dipilih yang berumur \pm 8 bulan

2. Diambil daging buah kelapa kemudian di cuci.

3. Daging buah kelapa muda dipotong menjadi segi 4

4. Dibuat larutan gula dengan konsentrasi $55 \%, 65 \%$, dan $75 \%$

5. daging buah kelapa muda ditimbang, dibagi sama rata dan kemudian dimasukkan dalam larutan gula.

6. Daging buah kelapa muda dimasak hingga mendidih selama 10 menit

7. Daging buah kelapa didinginkan pada suhu ruang, kemudian dimasukkan dalam botol jar sampai pada batas yang telah ditentukan

8. Botol jar yang telah berisi buah kelapa muda dipanaskan kembali selama 15 menit tanpa ditutup, untuk menghilangkan udara yang ada dalam botol jar

9. Botol jar ditutup kemudian disterilisasi selama 15 menit

10. Produk didinginkan kemudian disimpan

\section{Pengamatan}

Pengamatan dilakukan dengan melakukan uji organoleptik (warna, bau, rasa, penampakan dan tekstur) dari produk dan pengujian mikrobiologi (Alt, kapang, khamir, dan proksimat). 


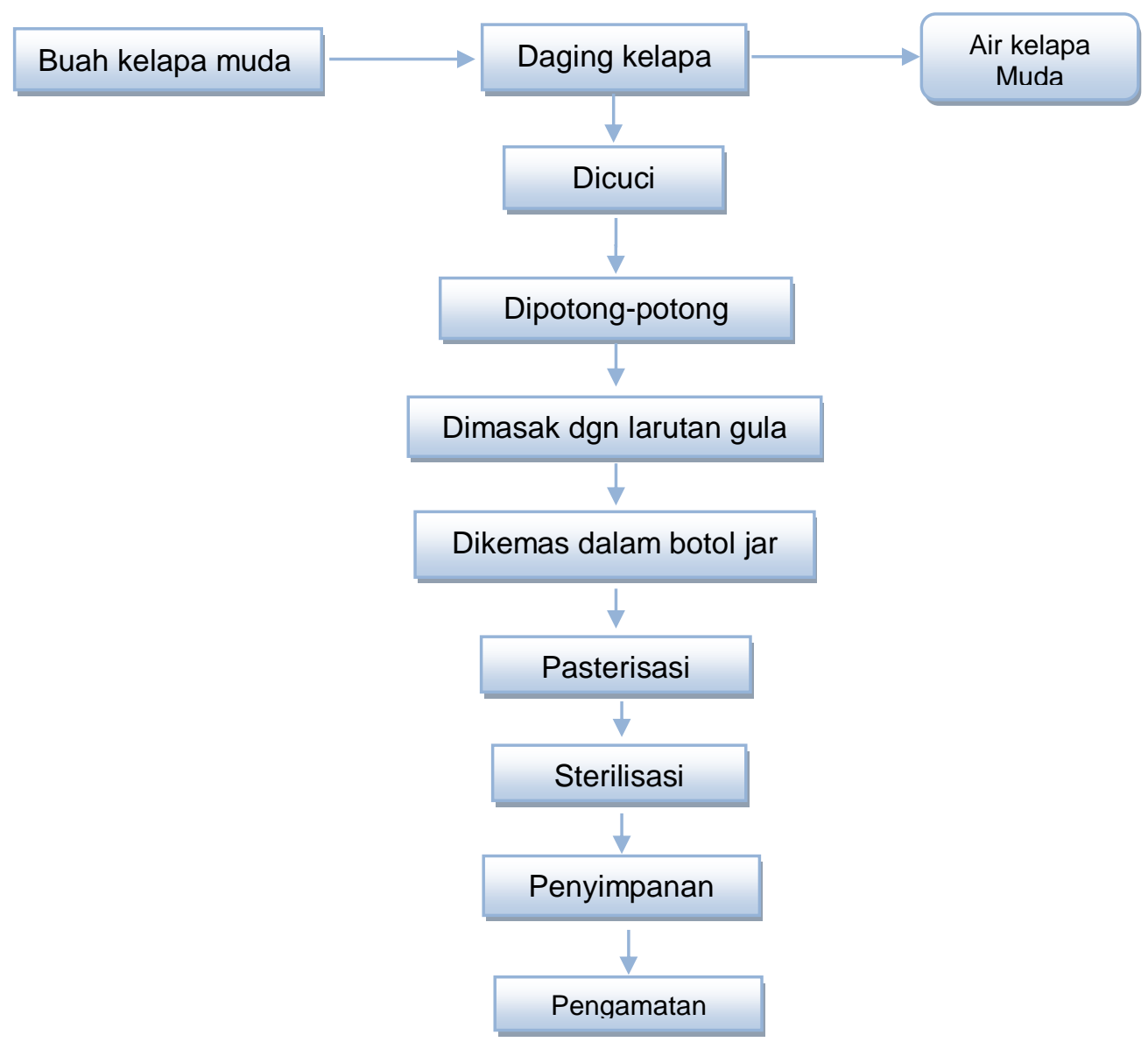

Gambar 1.Diagram Alir Pembuatan

\section{HASIL DAN PEMBAHASAN}

\section{Penelitian pendahuluan}

Pada penelitian pendahuluan dilakukan percobaan:

a) Daging buah kelapa muda yang berumur 8 bulan(dipisahkan dengan air kelapa) dipotong-potong. Kemudian air kelapa muda yang sudah dipisahkan ditambahkan gula dengan presentasi 10,20 dan 30\%. Daging buah kelapa muda ditimbang kemudian dibagi rata dan dimasukkan kedalam masingmasing konsentrasi air kelapa yang sudah ditambahkan gula. Kemudian keseluruhan perlakuan dimasak hingga mendidih selama 10 menit. Selanjutnya didinginkan dan dikemas menggunakan kemasan plastik, plastik stand up, dan botol jar. Selanjutnya di pasturisasi dan disterilisasi. Setelah disimpan dan diamati hasilnya produk yang dikemas dengan plastik dan plastik stand up pouch hanya bertahan selama dua hari, sedangkan untuk kemasan botol jar hanya bertahan selama 1 minggu.

b) Dengan perlakuan yang sama seperti diatas diamati juga penampakan dari masing-masing perlakuan dengan hasil setelah pemasakan warna dari air kelapa muda berubah menjadi ungu. Diduga perubahan warna tersebut disebabkan oleh noda yang keluar dari buah kelapa muda yang pada saat diambil dagingnya terikut dengan bagian keras dari bagian dalam tempurung 
kelapa muda pada saat daging buah kelapa muda tersebut dipanaskan.

c) Daging buah kelapa yang dimasak dengan gula dengan perlakuan yang sama seperti diatas dan dengan penambahan bahan pengawet makanan (natrium benzoat) memberikan hasil pada produk dengan kemasan plastik dapat bertahan selama 1 minggu sedangkan pada produk dengan kemasan botol jar dapat bertahan lebih dari 1 minggu.

d) Dilakukan juga perbandingan dengan menggunakan daging buah kelapa muda yang telah dicuci dan dimasak dengan air (bukan air kelapa muda) yang tidak menggunakan gula dengan perlakuan kemasan yang sama dengan diatas diperoleh hasil yaitu produk yang dikemas menggunakan botol jar dapat bertahan selama 1 bulan sedangkan untuk kemasan plastik, dan plastik stand up pouch hanya bertahan selama 1 minggu. Perbedaan daya tahan ini disebabkan produk yang dikemas dengan kemasan plastik tidak bisa dilakukan proses sterilisasi. Sehingga diduga masih terdapat bakteri yang dapat menyebabkan proses pembusukan.

e) Dilakukan penelitian pendahuluan kembali dengan kondisi perlakuan daging buah kelapa dicuci kemudian dimasak dalam larutan gula dengan konsentrasi 55\%,65\%, dan 75\% (tidak menggunakan air kelapa) dan ditambahkan pengawet makanan natrium benzoat diperoleh hasil produk dengan kemasan botol jar dapat bertahan lebih dari 1 bulan. Dalam tahap ini produk dalam bentuk sirup gula.

\section{Penelitian lanjutan}

Berdasarkan hasil pada penelitian pendahuluan diputuskan untuk melanjutkan penelitian dengan perlakuan penambahan gula dengan konsentrasi $55 \%$, 65\%, dan $75 \%$ atau dalam hal ini produk dalam bentuk sirup gula dan dikemas hanya menggunakan botol jar agar bisa dilakukan proses pasterisasi dan sterilisasi dan ditambahkan pengawet makanan natrium benzoat $1 \%$ dalam tiap perlakuan.

Dari hasil perlakuan tersebut dilakukan pengujian organoleptik pada produk dan diperoleh hasil seperti berikut.

Tabel 1. Hasil organoleptik Aroma

\begin{tabular}{ccccc}
\hline \multirow{2}{*}{ Kode } & \multicolumn{4}{c}{ Lama Penyimpanan (Rata-Rata) } \\
\cline { 2 - 5 } & B0 & B1 & B2 & B3 \\
\hline A0 & $3.515^{\mathrm{a}}$ & $3.435^{\mathrm{a}}$ & $3.48^{\mathrm{ab}}$ & $3.295^{\mathrm{ab}}$ \\
A1 & $3.62^{\mathrm{a}}$ & $3.385^{\mathrm{a}}$ & $3.415^{\mathrm{ab}}$ & $3.12^{\mathrm{ab}}$ \\
A2 & $3.465^{\mathrm{ab}}$ & $3.47^{\mathrm{ab}}$ & $3.4^{\mathrm{ab}}$ & $3.12^{\mathrm{ab}}$ \\
A3 & $3.55^{\mathrm{ab}}$ & $3.225^{\mathrm{ab}}$ & $3.36^{\mathrm{b}}$ & $3.105^{\mathrm{ab}}$ \\
\hline
\end{tabular}

\section{Aroma}

Dari hasil pengolahan data statistik menunjukan bahwa tidak ada perbedaan yang nyata pada tingkat kesukaan terhadap

aroma pada perlakuan penyimpanan, tetapi memberikan perbedaan yang nyata pada tingkat kesukaan terhadap aroma pada 
perlakuan perbedaan penambahan gula. Dengan kesimpulan aroma masih disukai walaupun sudah disimpan sampai 6 minggu

Tabel 2. Hasil organoleptik Rasa dengan kisaran angka 3-4 yang berarti masih disukai oleh panelis.

\begin{tabular}{ccccc}
\hline \multirow{2}{*}{ Kode } & \multicolumn{4}{c}{ Lama Penyimpanan (Rata-Rata) } \\
\cline { 2 - 5 } & B0 & B1 & B2 & B3 \\
\hline A0 & $2.6^{\mathrm{b}}$ & $2.6^{\mathrm{bc}}$ & $2.62^{\mathrm{bc}}$ & $2.6^{\mathrm{bC}}$ \\
A1 & $3.595^{\mathrm{a}}$ & $3.775^{\mathrm{a}}$ & $3.73^{\mathrm{a}}$ & $3.705^{\mathrm{a}}$ \\
A2 & $2.39^{\mathrm{d}}$ & $2.245^{\mathrm{d}}$ & $2.325^{\mathrm{d}}$ & $2.4^{\mathrm{d}}$ \\
A3 & $2.51^{\mathrm{bcd}}$ & $2.485^{\mathrm{cd}}$ & $2.29^{\mathrm{d}}$ & $2.37^{\mathrm{bcd}}$ \\
\hline
\end{tabular}

\section{Rasa}

Pada tabel diatas terlihat bahwa ratarata tingkat kesukaan rasa yang paling disukai berada pada perlakuan A1 yaitu produk dengan penambahan gula sebanyak $55 \%$ dengan angka uji organoleptik berkisar antara 3,59-3,75 dengan asumsi (agak suka-

\section{Warna}

Dari hasil analisis statistikdiketahui bahwa ada perbedaan yang nyata antara perlakuan penambahan gula yang berbeda-
suka).Dengan kesimpulan tingkat kemanisan yang menjadi faktor kesukaan dari para panelis untuk perlakuan $\mathrm{A} 2$ dan $\mathrm{A} 3$ yaitu penambahan gula 65 dan $75 \%$ sudah sangat berlebih, pada produk A0 tidak disukai karena tidak ditambahkan dengan gula.

beda dengan lama penyimpanan. Hasil uji organoleptik terhadap warna ditunjukkan pada Tabel 4..

Tabel3. Hasil organoleptik Warna

\begin{tabular}{ccccc}
\hline \multirow{2}{*}{ Kode } & \multicolumn{4}{c}{ Lama Penyimpanan (Rata-Rata) } \\
\cline { 2 - 5 } & B0 & B1 & B2 & B3 \\
\hline A0 & $4.6^{\mathrm{a}}$ & $4.305^{\mathrm{a}}$ & $4.695^{\mathrm{a}}$ & $4.855^{\mathrm{a}}$ \\
A1 & $4.56^{\mathrm{a}}$ & $4.345^{\mathrm{a}}$ & $4.445^{\mathrm{a}}$ & $4.735^{\mathrm{a}}$ \\
A2 & $3.02^{\mathrm{b}}$ & $3.1^{\mathrm{b}}$ & $2.925^{\mathrm{b}}$ & $2.595^{\mathrm{b}}$ \\
A3 & $2.805^{\mathrm{b}}$ & $2.65^{\mathrm{b}}$ & $2.855^{\mathrm{b}}$ & $2.59^{\mathrm{b}}$ \\
\hline
\end{tabular}

Dari tabel tersebut dapat dilihat bahwa warna produk kelapa dalam sirupyang paling disukai berada pada perlakuan produk tanpa penambahan gula dan penambahan gula dengan konsentrasi 55\% dengan angka berkisar antara 4.305-4,855 dengan asumsi suka hingga sangat suka. Hal ini dikarenakan penambahan gula dapat mempengaruhi warna dari produk kelapa dalam sirup dimana semakin banyak gula yang ditambahkan maka semakin keruh produk kelapa dalam sirup yang dihasilkan ${ }^{6}$. 
Tabel 4. Hasil organoleptik Tekstur

\begin{tabular}{ccccc}
\hline \multirow{2}{*}{ Kode } & \multicolumn{4}{c}{ Lama Penyimpanan (Rata-Rata) } \\
\cline { 2 - 5 } & B0 & B1 & B2 & B3 \\
\hline A0 & $3.775^{\mathrm{a}}$ & $3.77^{\mathrm{a}}$ & $3.685^{\mathrm{a}}$ & $3.88^{\mathrm{a}}$ \\
A1 & $3.79^{\mathrm{a}}$ & $3.63^{\mathrm{a}}$ & $3.91^{\mathrm{a}}$ & $3.835^{\mathrm{a}}$ \\
A2 & $2.645^{\mathrm{cd}}$ & $3.1^{\mathrm{cd}}$ & $2.81^{\mathrm{b}}$ & $3.045^{\mathrm{bc}}$ \\
A3 & $2.795^{\mathrm{d}}$ & $2.655^{\mathrm{d}}$ & $2.44^{\mathrm{d}}$ & $2.515^{\mathrm{d}}$ \\
\hline
\end{tabular}

\section{Tekstur}

Dari data pada tabel diatas dapat dilihat tingkat kesukaan terhadap tekstur hanya dipengaruhi oleh penambahan gula dan tidak dipengaruhi oleh lama penyimpanan.

Ciri fisik yang perlu dipertahankan dari daging buah kelapa muda adalah sifatnya yang kenyal. Dalam keadaan yang normal sifat kekenyalan yang alami ini ditunjang oleh gula galaktomanan. Galaktomanan tergolong pada polisakarida yang hampir seluruhnya larut dalam air membentuk larutan kental dan dapat membentuk gel ${ }^{7}$. Dalam pembuatan produk kelapa dalam sirup sifat lunak dan kenyal sangat berperan penting terhadap penerimaan konsumen dalam hal ini para panelis dalam melakukanuji organoleptik.
Penambahan gula dalam penelitian ini selain menjadikannya sebagai media pengawet alami juga berperan untuk meningkatkan kandungan gula agar supaya diperoleh sifat organoleptik yang disenangi oleh konsumen. Sehingga dapat disimpulkan penambahan gula yang berlebih akan mempengaruhi tingkat kekenyalan dari daging buah kelapa. Dimana semakin banyak gula yang ditambahkan maka tingkat kekenyalannyapun semakin tinggi dan menjadi tidak disukai oleh konsumen/panelis.

\section{Mikrobiologi}

Pada penelitian ini juga dilakukan analisis mikrobiologi yaitu total bakteri dan kapang dengan hasilnya sebagai berikut.

Tabel 5. Hasil Pengujian Mikrobiologi

\begin{tabular}{cccc}
\hline Kode & Bakteri & Kapang & Khamir \\
\hline A0B0 & 128 & 0 & 0 \\
A1B0 & 1 & 0 & 0 \\
A2B0 & 55 & 0 & 0 \\
A3B0 & 1 & 0 & 0 \\
A0B3 & 170 & $3,10^{2}$ & 0 \\
A1B3 & 73 & $1,10^{3}$ & 0 \\
A2B3 & 61 & $2,10^{2}$ & $1,10^{2}$ \\
A3B3 & 36 & 0 & 0 \\
\hline
\end{tabular}

Gula mampu memberi stabilitas mikroorganisme pada suatu produk makanan jika diberikan pada konsentrasi yang cukup (diatas $70 \%$ padatan terlarut), sehingga dipakai sebagai salah satu kombinasi dari teknik pengawetan bahan pangan ${ }^{8}$. Apabila gula ditambahkan pada bahan pangan (pembuatan manisan) dalam konsentrasi yang tinggi (paling sedikit 40\%) sebagian air yang ada menjadi tidak tersedia untuk pertumbuhan mikroorganisme (gula menghidrasi air) dan aktivitas air (Aw) dari 
bahan pangan berkurang. Hal inilah yang menyebabkan pertumbuhan bakteri pada produk yang ditambahkan gula dan yang tidak ditambahkan gula memberikan hasil yang berbeda. Dalam pembuatan kelapa dalam sirup menggunakan teknik pengawetan yang sering digunakan dalam pembuatan manisan buah yaitu kadar gula yang tinggi, pemanasan, penyimpanan dalam wadah tertutup, dehidrasi, dan penggunaan bahan kimia berupa benzoat.

\section{Pengujian Proksimat}

Analisis proksimat memiliki manfaat sebagai penilaian kualitas bahan pangan terutama pada standar zat makanan yang seharusnya terkandung di dalamnya. Pengujian proksimat pada produk kelapa dalam sirup untuk mengidentifikasi kandungan nutrisi berupa protein, lemak dan kadar abu. Hasil pengujian proksimat pada produk kelapa dalam sirup adalah sebagai berikut:

Tabel 6. Hasil Pengujian Proksimat

\begin{tabular}{cccc}
\hline Kode & Protein & Lemak & Kadar abu \\
\hline A0B0 & 1,13 & 1,17 & 0,20 \\
A1B0 & 1,47 & 1,22 & 0,33 \\
A2B0 & 1,70 & 1,58 & 0,28 \\
A3B0 & 1,37 & 1,86 & 0,23 \\
\hline
\end{tabular}

Dari hasil pengujian diperoleh data nilai protein berkisar antara $1,13-1,70 \%$. Nilai ini dianggap sesuai dengan literatur yang menyatakan kandungan protein yang terkandung dalam kelapa muda yaitu sebesar 1,0\%. Yang tidak berbeda jauh dengan hasil yang didapatkan. Sementara untuk kandungan lemak pada kelapa muda menurut literatur yaitu sebesar 0,9\%. Sedangkan hasil yang diperoleh dalam pengujian lemak berkisar antara 1,22$1,86 \%$. Hal ini diduga disebabkan karena perbedaan umur buah kelapa yang digunakan dalam penelitian dengan variasi umur kelapa muda dalam literatur tidak dijelaskan secara spesifik. Sementara untuk pengujian kadar abu bertujuan untuk mengetahui kandungan zat anorganik yang diperoleh dari pembakaran zat organik. Penentuan kadarabu ada hubungannya dengan kandungan mineral pada bahan pangan. Mineral yang terdapat dalam bahan terdiri dari 2 jenis garam yaitu garam organik misalnya asetat, pektat, malat, dan garam anorganik misalnya karbonat, fosfat, klorida, sulfat dan nitrat. Proses untuk menentukan jumlah kandungan dan komposisi abu atau mineral tergantung dari jenis bahan dan cara pengabuannya ${ }^{9}$. Berdasarkan hasil penelitian kadar abu yang diperoleh berkisar antara 0,20-0,33\% menunjukan bahwa kandungan zat anorganik relatif sedikit pada daging buah kelapa.

\section{KESIMPULAN}

Dari hasil penelitian yang telah dilakukan diperoleh kesimpulan bahwaperlakuan yang terbaik adalah A1B2 yaitu produk dengan penambahan gula $55 \%$ yang disimpan selama 6 minggu.Pengolahan kelapa muda dalam sirup gula dan dikemas dalam botol jar dapat memberikan ketahanan pada kelapa muda sehingga memiliki waktu simpan yang cukup lama. 


\section{DAFTAR PUSTAKA}

1 Betsy, C dan D. Pakasi. 2013 Pengembangan Kelapa Sebagai Komoditi Unggulan Daerah Sulawesi Utara Dengan Pendekatan Klaster Industri. Seminar Nasional: Menggagas Kebangkitan Komoditas Unggulan Lokal Pertanian dan Kelautan Fakultas Pertanian Universitas Trunojoyo Madura

2 Sumantri, Rohman, Abdul. 2007. Analisis Makanan. Gajah Mada University Press. Yogyakarta.

3 Sumoharjo, T., 2008. Penyelenggaraan Pemerintah Daerah Melalui Pengembangan Daya Saing Berbasis Potensi Daerah. Fokusmedia

4 Barlina R. Potensi buah kelapa muda untuk kesehatan dan pengolahannya. Jurnal Penelitian Tanaman Industri. 2004; 3(2):4660

5 Asni, N., LindaYanti, Muzirman, N. Dewi, S. Kiki, M. Nur Imdah, Hasniarti dan H. Rustan. 2005. Pengkajian Teknologi Penanganan Pasca Panen Mendukung Agro Industri Kelapa. Laporan Hasil Kegiatan. Balai Pengkajian Teknologi Pertanian, Jambi

6 Yanti, L dan N. Asni. 2014. Teknologi Pengolahan Sirup Kelapa Ramah Lingkungan Untuk Pemberdayaan Petani di Lahan Pasang Surut Provinsi Jambi. Prosiding Konferensi Nasional Kelapa VIII

7 Barlina, dkk. 2007. Pengaruh Perbandingan Air Kelapa dan Penambahan Daging Kelapa Muda Serta Lama Penyimpanan Terhadap Serbuk Minuman Kelapa. Jurnal Littri. Balai Penelitian Tanaman Kelapa dan Palma Lain (Balitka). 13(12) : 73-80.

8 Barus, P. 2009. Pemanfaatan Bahan Pengawet Dan Antioksidan Alami Pada Industri Bahan Makanan. Universitas Sumatra Utara. Medan.

9 Setiawan, O dan A. Sunarya. 2005.Teknik Pengawetan Buah Kelapa Muda
Menggunakan Natrium Metasulfit. Buletin Teknik Pertanian Vol. 10, Nomor 1.

10 Adisasmita, R. 2008. Pengembangan Wilayah : Konsep dan Teori. Penerbit Graha IImu. Yogyakarta

11 Kuncoro M., 2004. Otonomi dan Pengembangan Daerah: Reformasi, Perencanaan, Strategi dan Peluang. Erlangga Jakarta

12 Eko, S. 2010. Blansing dan Pasteurisasi. Diakses: 22 Maret 2015. http://hawusiwa.blogspot.com/2010/03/blansi ng-dan-pasteurisasi.html.Jakarta. 